\title{
Distribution of quinolones, sulfonamides, tetracyclines in aquatic environment and antibiotic resistance in Indochina
}

\author{
Satoru Suzuki ${ }^{1}$ and Phan Thi Phuong Hoa ${ }^{2}$ \\ ${ }^{1}$ Center for Marine Environmental Studies, Ehime University, Matsuyama, Ehime, Japan \\ ${ }^{2}$ Vietnam Type Culture Collection, Institute of Microbiology and Biotechnology, Vietnam National University, Hanoi, Vietnam
}

\section{Edited by:}

David W. Graham, Newcastle

University, UK

Reviewed by:

Charles Knapp, University of Strathclyde, UK

Veljo Kisand, University of Tartu, Estonia

Tong Zhang, The University of Hong

Kong, Hong Kong

${ }^{*}$ Correspondence:

Satoru Suzuki, Center for Marine

Environmental Studies, Ehime

University, Matsuyama, Ehime

790-8577, Japan.

e-mail: ssuzuki@ehime-u.ac.jp

\begin{abstract}
Southeast Asia has become the center of rapid industrial development and economic growth. However, this growth has far outpaced investment in public infrastructure, leading to the unregulated release of many pollutants, including wastewater-related contaminants such as antibiotics. Antibiotics are of major concern because they can easily be released into the environment from numerous sources, and can subsequently induce development of antibiotic-resistant bacteria. Recent studies have shown that for some categories of drugs this source-to-environment antibiotic resistance relationship is more complex. This review summarizes current understanding regarding the presence of quinolones, sulfonamides, and tetracyclines in aquatic environments of Indochina and the prevalence of bacteria resistant to them. Several noteworthy findings are discussed: (1) quinolone contamination and the occurrence of quinolone resistance are not correlated; (2) occurrence of the sul sulfonamide resistance gene varies geographically; and (3) microbial diversity might be related to the rate of oxytetracycline resistance.
\end{abstract}

Keywords: Indochina, environment, quinolone, sulfonamide, tetracycline, resistance gene, bacteria

\section{INTRODUCTION}

Since antibiotics were first discovered in 1928, they have been widely used in human and animal medicine. However, most antibiotics are excreted and enter the soil or water environments through wastewater and fertilization with manure (Kümmerer, 2003). Antibiotic contamination of the natural environment has been documented in many countries, including those of Europe, North America, and East Asia, and areas of antibiotic contamination are widespread throughout the region (Segura et al., 2009). But not much information is available for Southeast Asia and Africa.

The pathways whereby residual antibiotics enter the environment are varied and include wastewater effluent discharge and runoff and leaching from land fertilized with agricultural or human waste. An increasing number of reports show a rise in the occurrence and distribution of antibiotics in surface waters in Europe (Hirsch et al., 1999; McArdell et al., 2003), the USA (Lindsey et al., 2001; Kolpin et al., 2002; Kim and Carlson, 2007), and Canada (Metcalfe et al., 2004). Cases of antibiotic contamination of wastewater are also well-known (Göbel et al., 2005; and others). Some antibiotics can be found in ground water (Baquero et al., 2008). In China, antibiotics have been found in animal wastewater, pond water, animal farm effluents, and rivers. The most frequently detected antibiotics in China include sulfamethazine $(75 \%)$, oxytetracycline $(64 \%)$, tetracycline $(60 \%)$, sulfadiazine $(55 \%)$, and sulfamethoxazole $(51 \%)$, which were found at maximum concentrations of 211, 72.9, 10.3, 17.0, and $63.6 \mathrm{ppb}$, respectively (Wei et al., 2011). In Korea, environmental contamination with tetracyclines and sulfonamides was reported at the ppb level (Ok et al., 2011). Recent excellent reviews by Kümmerer (2009a,b) summarize contamination of the environment with antibiotics and the spread of antibiotic resistance.
This manuscript will focus on Indochina environment having unique situation as following.

\section{WHY INDOCHINA? - SPECIFIC SITUATION OF INDOCHINA}

Unlike the socioeconomic-unified continents of Europe and North America, Asia is more geographically and culturally disjunct, and cannot be readily grouped as a single geopolitical entity. It therefore remains difficult to obtain a generalized theory of antibiotic and antibiotic resistance contamination across all Asian countries. This manuscript focuses specifically on the region of Indochina and the major antibiotics in this area, including quinolones, sulfonamides, and tetracyclines. Countries of "Indochina" include Vietnam, Thailand, Cambodia, Lao PDR, and Myanmar. Of these, Vietnam and Thailand have particularly become a center of rapid industrial development and economic growth; however this growth has far outpaced investment in public infrastructure, leading chemical pollution and sanitary issues.

Although Indochina is globally one of the most active regions of industrial growth and development, there remains few studies on antibiotic contamination relative to their Western and East Asian counterparts (Le and Munekage, 2004; Nhiem et al., 2006; Managaki et al., 2007; Duong et al., 2008; Zhang et al., 2009; Hoa et al., 2011; Takasu et al., 2011). From Asian aquatic environments contamination levels are highly variable, ranging from scales of ppm to ppt (Le and Munekage, 2004; Managaki et al., 2007; Duong et al., 2008; Hoa et al., 2011; Takasu et al., 2011). Table 1 summarizes the various antibiotic contaminants that have been detected in Indochina aquatic environments. Until now for antibiotic resistance in this area, major reports consisted of studies on Salmonella isolates (Ogasawara et al., 2008; Sirichote et al., 2010; and others). 
Table 1 | Antibiotics detected in aquatic environments of Indochina countries.

\begin{tabular}{|c|c|c|c|c|}
\hline Antibiotic classes & Compounds & Habitat & Concentration range (ppt) & Reference \\
\hline \multirow[t]{13}{*}{ Sulfonamides } & Sulfamethoxazole & Shrimp pond & $0.01-6.06 \times 10^{6}$ & Le and Munekage (2004) \\
\hline & & Urban drainage & $190-330$ & Managaki et al. (2007) \\
\hline & & Canal & $37-174$ & Managaki et al. (2007) \\
\hline & & & $0.02-4330$ & Hoa et al. (2011) \\
\hline & & Mekong river & $20-33$ & Managaki et al. (2007) \\
\hline & & Pig farm & n.q. -227 & Managaki et al. (2007) \\
\hline & & & $68.2-422$ & Hoa et al. (2011) \\
\hline & Sulfamethazine & Urban drainage & $110-251$ & Managaki et al. (2007) \\
\hline & & Canal & $62-328$ & Managaki et al. (2007) \\
\hline & & & $16.1-66.2$ & Hoa et al. (2011) \\
\hline & & Mekong river & $15-28$ & Managaki et al. (2007) \\
\hline & & Pig farm & $18512-19152$ & Managaki et al. (2007) \\
\hline & & & $6.78-6662$ & Hoa et al. (2011) \\
\hline \multirow[t]{8}{*}{ Trimethoprim } & Trimethoprim & Shrimp pond & $0.08-1.04 \times 10^{6}$ & Le and Munekage (2004) \\
\hline & & & n.d.-85 & Hoa et al. (2011) \\
\hline & & Urban drainage & $27-46$ & Managaki et al. (2007) \\
\hline & & Canal & $315-44$ & Managaki et al. (2007) \\
\hline & & & 23-1808 & Hoa et al. (2011) \\
\hline & & Mekong river & $7-19$ & Managaki et al. (2007) \\
\hline & & Pig farm & $30-84$ & Managaki et al. (2007) \\
\hline & & & n.d. -34.6 & Hoa et al. (2011) \\
\hline \multirow[t]{6}{*}{ Macrolides } & Erythromycin & Urban drainage & $29-39$ & Managaki et al. (2007) \\
\hline & & Canal & $31-41$ & Managaki et al. (2007) \\
\hline & & & $61.1-2246$ & Hoa et al. (2011) \\
\hline & & Mekong river & $9-12$ & Managaki et al. (2007) \\
\hline & & Pig farm & n.q. & Managaki et al. (2007) \\
\hline & & & n.d.-63.9 & Hoa et al. (2011) \\
\hline \multirow[t]{7}{*}{ Fluroquinolones } & Norfloxacin & Shrimp pond & $0.06-6.06 \times 10^{6}$ & Le and Munekage (2004) \\
\hline & & Hospital wastewater & $1.5-15.2 \times 10^{3}$ & Duong et al. (2008) \\
\hline & & & $4.62-2560$ & Takasu et al. (2011) \\
\hline & Oxolinic acid & Shrimp pond & $0.01-2.5 \times 10^{6}$ & Le and Munekage (2004) \\
\hline & Ciprofloxacin & Hospital wastewater & $1.2-10.9 \times 10^{3}$ & Duong et al. (2008) \\
\hline & & & 328 & Takasu et al. (2011) \\
\hline & Ofloxacin & Canal & $185-782$ & Takasu et al. (2011) \\
\hline
\end{tabular}

n.q., not quantifiable due to overlapped interfering peak.

Large amounts of antibiotics are used for human medicine, livestock farming, and aquaculture in Southeast Asia. In addition, we observed that antibiotics are used as additives in ice to prevent decay of harvested fish in fish markets. It is believed that high concentrations of antibiotics applied in this manner will remain in the fish, and will then be taken in by people upon consumption. Such widespread antibiotic contamination of the environment and food supply likely promotes the development of antibioticresistant bacteria, both in the environment and within the human intestine. Prior to the early 2000s, few studies addressed antibiotic contamination in Indochina (Le and Munekage, 2004), although the occurrence of antibiotic-resistant bacteria in the region was reported (Kim et al., 2004; Le et al., 2005; Zhang et al., 2009). However, recent studies on drug contamination, combined with detection of antibiotic-resistant bacteria and/or resistance genes, have provided a clearer picture of the problem in this area of Asia (Hoa et al., 2011; Takasu et al., 2011).
In Indochina, an integrated agriculture-aquaculture farming system known as VAC (Vegetation, Aquaculture, and Cage) is common. The VAC system is a recycling farm, typically consisting of a vegetable field, an aquaculture pond, and caged animals, and has been practiced since the 1980s. In the VAC system, livestock manure (usually from pigs, chickens, and ducks) is directly transported to fish ponds and to vegetable and rice fields. This untreated sewage and wastewater from the livestock operations is used for fish culture and for fertilization of the vegetable fields. The animal manure contributes to the eutrophication of pond water, which enhances phytoplankton growth. The VAC system is considered a very economical method of recycling farming (Hop, 2003); however, the heavy use of antibiotics in livestock increases the prevalence of enteric antibiotic-resistant bacteria and the potential for antibiotic-resistant pathogenic bacteria to arise. Subsequent discharge of antibiotic residues in farm waste likely increases the number of antibiotic-resistant bacteria in the environment, which 
in turn promotes the further selection and transfer of antibiotic resistance genes within the microbial community in the surrounding environment (Petersen and Dalsgaard, 2003; Heuer and Smalla, 2007). Recent study by Dang et al. (2011) reported that enteric bacteria of pigs in VAC showed high resistance to nalidixic acid and enrofloxacin, which would be dispersed to water environment. Tetracycline resistance was found at all times with high frequency $(80 \%<)$. The VAC system can be thought as a "bazaar of antibiotic resistance." That is, the abundance of antibiotic-resistant bacteria and genes initially increases in the intestinal tracts of livestock as a result of exposure to high concentrations of various antibiotics. Next, horizontal gene transfer occurs among various bacteria in the environment surrounding the VAC operation. Antibiotic resistance genes persist and spread among environmental bacteria through acquisition and recombination. Finally, the antibiotic resistance genes move to other environments via water use and the food supply. The antibiotic resistance genes are brought together, exchanged, and spread in VAC systems. If the antibiotic-resistant bacteria come into contact with human pathogens and commensal bacteria, the risk to human health may increase significantly. Although there are many snapshot reports of antibiotic resistance (reviewed in Zhang et al., 2009), further dynamic study is needed to evaluate the risks posed by the presence of antibiotic resistance genes in the aquatic environments of developing countries in Asia.

\section{QUINOLONE RESISTANCE}

Fluoroquinolones (FQs) are fully synthetic antibiotics that are widely used in humans, animals, and fish (Grave et al., 1999; Le and Munekage, 2004; Samanidou et al., 2005; Kemper, 2008). The antibacterial mechanism of FQs is based on inhibition of bacterial DNA gyrase or topoisomerase IV, which are enzymes essential for DNA replication. First-generation FQs are piromidic acid, oxolinic acid, and nalidixic acid, which were widely used in aquaculture in the 1970s in Japan. In tropical Asian countries, oxolinic acid still appears to be one of the major drugs used (Gräslund et al., 2003; Le and Munekage, 2004). Second-generation (ciprofloxacin, CIP and norfloxacin, NOR) and third-generation (levofloxacin, LEV and its enantiomer ofloxacin, OFL) compounds are used in hospitals and animal husbandry in Indochina (Takasu et al., 2011).

The FQs are photo-degradable, with a half-life in pure water of 105 and $90 \mathrm{~min}$ for NOR and CIP, respectively (Burhenne et al., 1997). However, FQs in the environment are relatively stable in water and sediment (Kümmerer, 2004; Le and Munekage, 2004), which might be due to sorption onto particulates (Nowara et al., 1997). Lai and Lin (2009) reported that oxolinic acid and flumequine could be retained in sediment for 9.5-15 and 3.6-6.4 days, respectively. Such long half-lives in the environment pose a selective pressure for environmental bacteria. Although the bioavailability of antibiotics is suspected to decrease upon adsorption on clay and humic substances, no supporting evidence has been reported.

Holmström et al. (2003) reported that $74 \%$ of Thailand shrimp aquaculture farmers use antibiotics, primarily NOR. Le and Munekage (2004) reported detecting NOR at 0.5-3.5 ppm in the water column and $200-1500 \mathrm{ppm}$ in the sediment of intensive ponds and improved extensive ponds in Vietnam. Oxolinic acid could be detected in the water column at a concentration similar to that of NOR, but not in the sediment. The "water column concentration" indicates present inflow, while the "sediment concentration" indicates the value integrated over time (Takasu et al., 2011). The presence of antibiotics in both samples suggests that the compounds being used at present and are retained in the sediment.

Ciprofloxacin is commonly used with other drugs, such as griseofulvin, rifampicin, and oxytetracycline for shrimp larvae in Vietnam (Thuy et al., 2011). The most recent quantification of FQs in Indochina aquatic environments showed that the average concentrations were higher in Thailand (OFL, $7400 \mathrm{ppb}$; NOR, 209 ppb; CIP, 328 ppb; LOM, 67.4 ppb) than in Vietnam (OFL, 255 ppb; NOR, 41.1 ppb; CIP, 162 ppb; LOM, 25.3 ppb; Takasu et al., 2011). Both OFL and NOR were confirmed as major environmental contaminants in both countries; however, contamination at aquaculture sites was lower than at VAC farms and city canals in both countries. A recent decrease in drug application and/or dilution effects may explain the improved contamination situation in aquaculture settings. Since FQs are not natural compounds, it is believed that bacteria do not possess FQ resistance genes. However, bacteria resistant to FQs can be found easily. Several resistance mechanisms have been reported, including mutation of DNA gyrase (Fukuda et al., 1990), impermeability to FQs due to loss of porins, and extrusion by overexpressed efflux pumps (Hirai et al., 1986, 1987). A number of plasmid-mediated quinolone resistance (PMQR) genes ( $q n r A, q n r B$, and $q n r S$ ) have also been identified (Robicsek et al., 2006). These PMQR genes are transferred horizontally among bacteria and encode a protein of the pentapeptide repeat family that has been shown to block the actions of FQs on purified DNA gyrase and topoisomerase IV (Robicsek et al., 2006). The origin of these genes is thought to be chromosomes in aquatic bacteria (Poirel et al., 2005a,b; Cattoir et al., 2008). Thus, the aquatic environment is hypothesized to be a natural reservoir of FQ-resistant bacteria and resistance genes.

As mentioned above, the environmental concentration of FQs was found to be much higher in Thailand than in Vietnam. Despite the lower level of contamination, the occurrence rate of FQ-resistant bacteria was found to be higher in Vietnam than Thailand (Takasu et al., 2011). Takasu et al. (2011) demonstrated that there is no relationship between the concentration of FQs in the environment and the rate of bacterial resistance. Kümmerer (2003) reported that exposure to a sub-inhibitory concentration induces the emergence of resistant bacteria in aquatic environments. It was reported that FQs at concentrations 10-100 times lower than the MIC induce the expression of a functional gene (Herold et al., 2005), mutations (Gillespie et al., 2005), and morphological changes (Loubeyre et al., 1993) at the single-cell level. Low concentrations are thus effective inducers of drug-resistant bacteria. The effect of disinfectants on bacteria is considerably reduced in the presence of organic matter (Kawamura-Sato et al., 2008), suggesting that the actual active concentration in the environment might be lower than analysis suggests. The importance of low concentrations of FQs to the development of antibiotic resistance should not be ignored, and additional research involving both instrumental analyses and bioassays is needed to estimate the actual concentration of FQs acting upon environmental bacteria. 
A broad range of bacteria can acquire resistance to FQs, including enteric bacteria (Escherichia coli), pathogenic bacteria (e.g., Acinetobacter), and aquatic bacteria (e.g., Brevundimonus). Proteobacteria and Actinobacteria are the major taxa of FQ-resistant bacteria (Takasu et al., 2011), indicating that FQ-resistant bacteria are not limited to specific groups. It was hypothesized that bacteria from humans and animals as well as natural aquatic bacteria are potential reservoirs of FQ resistance genes. A number of resistance genes have been identified in FQ-resistant bacteria, including $q n r A, q n r B, q n r S$, and $a a c\left(6^{\prime}\right)-I b-c r$ (Takasu et al., 2011). Since $q n r A, q n r B$, and $q n r S$ are thought to have originated from the chromosomes of water-dwelling bacteria (Poirel et al., $2005 a, b)$, it is possible that these genes can be transferred from aquatic bacteria to human bacteria (Hernández et al., 2011). To date, PMQR genes including $a a c\left(6^{\prime}\right)-I b-c r$, which are linked with other drug resistance genes and are transferable, have only been discovered in Gammaproteobacteria such as Vibrio (Poirel et al., 2005a), Shewanella (Poirel et al., 2005b), and Aeromonas (Cattoir et al., 2008; Picao et al., 2008) in the environment. The number of FQ-resistant Salmonella enterica isolates found in Thailand increased in the late 1990s, and the resistant isolates possessed the same gyrA region, suggesting rapid spread of the resistant bacteria (Hakanen et al., 2001). The gyrA mutation is located on the chromosome, but recent research indicates that gyrA can also be transferred (Ferrandiz et al., 2000). Spreading of both resistant bacteria and chromosomal resistance genes might be a cause of the observed widespread drug resistance in Asia. However, precisely how FQ resistance genes are spread among various environments is not known, although mutation-based resistance and transferable genes should be considered. The dynamics of FQ resistance genes are of interest and importance from the viewpoints of human clinical and gene evolution studies.

\section{SULFONAMIDE RESISTANCE}

Sulfonamides, which are also synthetic antibiotics, have been widely used to treat bacterial and protozoan infections in humans, domestic animals, and aquaculture species since their introduction to clinical practice in 1935 (Perreten and Boerlin, 2003; Le and Munekage, 2004; Blahna et al., 2006). Sulfonamides inhibit folate biosynthesis by competing with the natural substrate $p$-aminobenzoic acid for binding to dihydropteroate synthase (DHPS), an enzyme in the folic acid synthesis pathway. While the use of sulfonamides in humans has decreased in developed countries, they are still frequently used in developing Asian countries due to their low cost (Macrolides are 1-3 \$/tablet, whereas sulfonamides are 2 cent/tablet in Vietnam). Sulfamethoxazole (SMX), a commonly used sulfonamide analog, was detected at ppm levels in shrimp ponds in Vietnam in the late 1990s (Le and Munekage, 2004). Although such levels are extremely high, SMX levels in rivers in Japan and Vietnam are typically around $100 \mathrm{ppt}$ in recent years (Managaki et al., 2007). This was confirmed in various locations in Vietnam (Hoa et al., 2011), where concentrations were in the $600-4000 \mathrm{ppt}$ range throughout the year in a city canal. Trimethoprim was detected in the $20-1800$ ppt range as well, probably because it is often used with SMX. In livestock farm wastewater, the concentration of SMX was lower, in the 68600 ppt range, whereas that of sulfamethazine was much higher
(400-6000 ppt). Other sulfonamides were either not detected or found at trace levels, suggesting that SMX and sulfamethazine are the major sulfonamides in use in Vietnam at present.

Since sulfonamides inhibit the formation of dihydrofolic acid (Perreten and Boerlin, 2003), bacterial resistance to sulfonamides can occur through mutations in the chromosomal DHPS gene $(f \circ l P)$ or through acquisition of an alternative DHPS gene $(s u l)$ whose product has a low affinity for sulfonamides (Perreten and Boerlin, 2003). Acquisition of sulfonamide resistance through sul genes is the most prevalent mechanism (Enne et al., 2002; Perreten and Boerlin, 2003). Sulfonamide resistance is globally prevalent among human and animal pathogens (Kerrn et al., 2002; Perreten and Boerlin, 2003; Antunes et al., 2005); however, the presence of sul genes is not equally distributed among bacterial populations (Kerrn et al., 2002; Antunes et al., 2005; Hammerum et al., 2006). Reports from Asia are not uniform regarding the distribution of sul genes. The sul2 gene, which is related to class I integron, is common in Acinetobacter isolated from fish farms and chicken manure in Thailand (Agersø and Petersen, 2007). However, Hoa et al. (2008) reported that sull was the major sul gene among SMX-resistant bacteria isolated from VAC farms, city canals, and aquaculture sites in Vietnam. Most of these reports were based on isolated bacteria, which may bias interpretation of results due to the processes of isolation; therefore, we cannot obtain an accurate assessment of the distribution of antibiotic resistance genes from culturable bacteria alone. A direct quantification approach indicated that sull is the major sulfonamide resistance gene in lagoon and river waters in the USA (Pruden et al., 2006). It is likely that such non-culture monitoring of antibiotic resistance genes will increase in the near future (for example, Pei et al., 2006). A culture-dependent study of SMX-resistant bacteria revealed that Acinetobacter is one of the major reservoirs of sul genes in Asian aquatic environments (Agers $\varnothing$ and Petersen, 2007; Hoa et al., 2011). Since Acinetobacter, especially $A$. baumannii, is known to be an important opportunistic pathogen with multi-drug resistance (Vila and Pachón, 2011), the risk posed by environmental A. baumannii to human health should be examined further. Low concentration of SMX can affect on bacterial nitrate metabolism and select bacterial species (Underwood et al., 2011), suggesting importance of trace contamination by SMX.

\section{TETRACYCLINE RESISTANCE}

Tetracyclines are a family of broad-spectrum antibiotics that includes tetracycline, oxytetracycline (OTC), chlortetracycline, doxycycline, and minocycline (Chopra and Roberts, 2001). These antibiotics inhibit protein synthesis in Gram-positive and Gramnegative bacteria by preventing the binding of aminoacyl-tRNA molecules to the 30S ribosomal subunit (Geigenmuller and Nierhaus, 1986; Ross et al., 1998). Owing to their broad-spectrum activity and low toxicity, tetracyclines are used in the treatment of a number of human skin and dental diseases. Tetracyclines are also used in agriculture as growth promoters in farm animals and are used widely as prophylaxes in plant agriculture and aquaculture around the world (Chopra and Roberts, 2001), including Southeast Asia (Thuy et al., 2011). The firstgeneration tetracyclines include OTC, chlorotetracycline, and 6demethylchlorotetracycloine, which were developed in the $1940 \mathrm{~s}$. 
Minocycline and doxycycline were launched as second-generation drugs in the 1960s (Thaker et al., 2010). A new glycylcycline derivative, tigecycline, which is active against most OTC-resistant bacteria, Acinetobacter, MRSA, and extended-spectrum $\beta$-lactamase (ESBL) producers, was licensed in 2005 (Livermore, 2005). Despite the variety of available analogs, OTC is still commonly used in animal production and aquaculture (Holmström et al., 2003; Nonaka et al., 2007; and others), although use as growth promoters has been banned in EU until 2006 (Castanon, 2007). As tetracyclineresistant bacteria, high occurrence of tetracycline-resistant Salmonella from human (50\%) and animals (pig 34\% and poultry 76\%) are reported in Vietnam (Vo et al., 2010), as well as Enterococcus and E. coli (both $80 \%<$; Dang et al., 2011). Similar results are known in Thailand, e.g., chicken (42\%) and chicken meat $(45 \%)$, and pork (11\%) and pork meat (20\%; Ogasawara et al., 2008).

Tetracycline resistance genes, tet series, from the resistant bacteria have been well-studied (Roberts, 2005; and others). The tet genes are classified by mechanism of action. Studies have indicated that some tet genes are persistent in aquaculture site without selective pressure (Tamminen et al., 2011), pristine environments and in animals (Gilliver et al., 1999; Rahman et al., 2008a,b), suggesting that they have a natural origin. Tracking of tet genes in aquatic environments, including pristine areas, has been examined in the USA (Pruden et al., 2006; Storteboom et al., 2010a,b), Japan (Kim et al., 2004; Nonaka et al., 2007), and other countries (Zhang and Zhang, 2011); however, similar research in Indochina aquatic environments is limited (Kobayashi et al., 2007a; Suzuki et al., 2008). Monitoring and phylogenetic analyses are needed if we are to obtain a thorough understanding of the origin and spread dynamics of tet genes. Kobayashi et al. (2007a) detected tet $(M)$, tet $(S)$, and tet $(W)$ genes throughout the Mekong River Delta. They found that $\operatorname{tet}(S)$ and $\operatorname{tet}(W)$ have only one genotype each, while tet $(M)$ has at least two genotypes. One tet $(M)$ genotype is identical to the gene encoded in various plasmids and transposons of Gram-positive and Gram-negative bacteria, and another is similar to a gene encoded in Tn1545 of Enterococcus faecalis ( $99 \%$ identity in PCR product, $170 \mathrm{bp} / 171 \mathrm{bp}$ ). Since the two types could be found in the same sample, it was assumed that more than one source of the gene exists. This hypothesis was partly confirmed by microbial diversity analysis using denatured gradient gel electrophoresis analysis, which indicated a positive relationship between the Shannon index $\left(\mathrm{H}^{\prime}\right)$ value and the tet gene detectionand OTC-resistant bacteria occurrence-rates across a wide area, ranging from the Mekong River and Tonle Sap Lake, Cambodia to the South China Sea (Suzuki et al., 2008).

Gene exchange and horizontal transfer among various bacterial species in natural environments have been demonstrated (Smets and Barkay, 2005). Ribosomal protection protein (RPP) genes, including tet $(M)$, tet $(S)$, and tet $(W)$, are transferred among bacteria (Chopra and Roberts, 2001), and this phenomenon was experimentally confirmed using combinations of marine bacteria (gene donors) and E. coli (Neela et al., 2009). However, another hypothesis was proposed by Kobayashi et al. (2007b), which holds that the RPP genes were derived through duplication and divergence of an ancient GTPase before the divergence of the three domains. The RPPs may have originally provided ribosomal protection against other chemical substances in the environment. It is known that exposing microbial assemblages to one toxicant can result in indirect selection for bacteria with resistance to multiple, chemically unrelated toxicants (Baker-Austin et al., 2006; Baker et al., 2006). For example, exposure to $\mathrm{Cd}$, Ni, ampicillin, and tetracycline significantly increases the frequency of bacterial resistance to multiple, chemically unrelated metals and antibiotics (Stepanauskas et al., 2006). Metals and antibiotics are known not only for being associated to similar efflux pumps, but also for inducing co-resistance (Baker-Austin et al., 2006; Baker et al., 2006). Aquatic environments in Indochina are highly contaminated with many kinds of persistent organic pollutants, metals (Suzuki and Takada, 2009), and antibiotics (Managaki et al., 2007; Hoa et al., 2011). Under such conditions, environmental bacteria can acquire drug resistance naturally over time as well as through horizontal gene transfer. Both transferable paralogous resistance genes and canonical resistance genes might be present in natural environments. From the viewpoint of both drug resistance and evolutionary biology, RPP genes are thus of considerable interest (Kobayashi et al., 2007b).

\section{CONCLUSION}

Indochina aquatic environments are particularly vulnerable to the development of antibiotic-resistant bacteria due to pollution with antibiotics and other chemicals in the absence of adequate wastewater treatment systems. Recent important findings concerning antibiotic resistance are as follows: (1) sub-lethal concentrations of antibiotics accelerate the development of antibiotic resistance (Yeh et al., 2009; Gullberg et al., 2010), and (2) chemicals other than antibiotics can promote development of antibiotic resistance (Alonso et al., 2001; Baker-Austin et al., 2006). Both of these scenarios are suspected to occur in natural environments, especially in Asian countries. Correlation between the number of antibiotic drugs detected and the occurrence of multi-drugresistant bacteria in Vietnam was found (Hoa et al., 2011), indicating that multi-drug contamination is almost certain to result in an increase in the prevalence of multi-drug-resistant bacteria in aquatic environments. It is important to note that contamination with various antibiotics correlates strongly with induction of multi-drug resistance, even if the contaminant concentration is low. Multi-drug resistance is a serious issue, particularly in Asia, and is likely to become of even greater concern in the future. Furthermore, contamination of antibiotics with trace concentrations can alter microbial ecosystem in terms of metabolism and diversity (Underwood et al., 2011), indicating the importance to consider unexpectedly effect than antimicrobial resistance. There is still a considerable gap in knowledge regarding the environmental chemistry and microbiology in the environment. Chemical and microbial monitoring in aquatic environments should thus be accelerated worldwide.

\section{ACKNOWLEDGMENTS}

This work was partly supported by the $21 \mathrm{COE}$ and GCOE Programs, Ehime University, MEXT, Japan, and Grant-in-Aids for Scientific Research from JSPS (19405004, 22241014, 22254001). 


\section{REFERENCES}

Agersø, Y., and Petersen, A. (2007). The tetracycline resistance determinant Tet 39 and the sulphonamide resistance gene sulII are common among resistant Acinetobacter spp. isolated from integrated fish farms in Thailand. J. Antimicrob. Chemother. 59, 23-27.

Alonso, A., Sánchez, P., and Martínez, J. L. (2001). Environmental selection of antibiotic resistance genes. Environ. Microbiol. 3, 1-9.

Antunes, P., Machado, J., Sousa, J. C., and Peixe, L. (2005). Dissemination of sulfonamide resistance genes (sul1, sul2, and sul3) in Portuguese Salmonella enterica strains and relation with integrons. Antimicrob. Agents Chemother. 49, 836-839.

Baker, B. J., Wright, M. S., Stepanauskas, R., and McArthur, J. V. (2006). Coselection of antibiotic and metal resistance. Trends Microbiol. 14, 176-182.

Baker-Austin, C., Wright, M. S., Stepanauskas, R., and McArthur, J. V. (2006). Co-selection of antibiotic and metal resistance. Trends Microbiol. 14, 176-182.

Baquero, F., Martínez, J.-L., and Cantón, R. (2008). Antibiotics and antibiotic resistance in water environments. Curr. Opin. Biotechnol. 19, 1-6.

Blahna, M. T., Zalewski, C. A., Reuer, J., Kahlmeter, G., Foxman, B., and Marrs, C. F. (2006). The role of horizontal gene transfer in the spread of trimethoprimsulfamethoxazole resistance among uropathogenic Escherichia coli in Europe and Canada. J. Antimicrob. Chemother. 57, 666-672.

Burhenne, J., Ludwig, M., Nikoloudis, P., and Spiteller, M. (1997). Primary photoproducts and half-lives. Environ. Sci. Pollut. Res. Int. 4, 10-15.

Castanon, J. I. R. (2007). History of the use of antibiotic as growth promoters in European poultry feeds. Poult. Sci. 86, 2466-2471.

Cattoir, V., Poirel, L., Aubert, C., Soussy, C. J., and Nordmann, P. (2008). Unexpected occurrence of plasmid-mediated quinolone resistance determinants in environmental Aeromonas spp. Emerging Infect. Dis. 14, 231-237.

Chopra, I., and Roberts, M. (2001). Tetracycline antibiotics: mode of action, applications, molecular biology, and epidemiology of bacterial resistance. Microbiol. Mol. Biol. Rev. 65, 232-260.

Dang, S. T. T., Petersen, A., Truong, D. V., Chu, H. T. T., and Dalsgaard, A. (2011). Impact of medicated feed on the development of antimicrobial resistance in bacteria at integrated pig-fish farms in Vietnam. Appl. Environ. Microbiol. 77, 4494-4498.

Duong, H. A., Pham, N. H., Nguyen, H. T., Hoang, T. T., Pham, H. V., Pham, V. C., Berg, M., Giger, W., and Alder, A. C. (2008). Occurrence, fate and antibiotic resistance of fluoroquinolone antibacterials in hospital wastewaters in Hanoi, Vietnam. Chemosphere 72, 968-973.

Enne, V. I., King, A., Livermore, D. M., and Hall, L. M. C. (2002). Sulfonamide resistance in Haemophilus influenzae mediated by acquisition of sul2 or a short insertion in chromosomal folP. Antimicrob. Agents Chemother. 46, 1934-1939.

Ferrandiz, M. J., Fenoll, A., Linares, J., and De La Campa, A. G. (2000). Horizontal transfer of parC and gyrA in fluoroquinolone-resistant clinical isolates of Streptococcus pneumoniae. Antimicrob. Agents Chemother. 44, 840-847.

Fukuda, H., Hosaka, M., Hirai, K., and Iyobe, S. (1990). New norfloxacin resistance gene in Pseudomonas aeruginosa PAO. Antimicrob. Agents Chemother. 34, 1757-1761.

Geigenmuller, U., and Nierhaus, K. H. (1986). Tetracycline can inhibit tRNA binding to the ribosomal $\mathrm{P}$ site as well as to the A site. Eur. J. Biochem. 161, 723-726.

Gillespie, S. H., Basu, S., Dickens, A. L., O'Sullivan, D. M., and McHugh, T. D. (2005). Effect of subinhibitory concentrations of ciprofloxacin on Mycobacterium fortuitum mutation rates. J. Antimicrob. Chemother. 56, 344-348.

Gilliver, M. A., Bennett, M., Begon, M., Hazel, S. M., and Hart, C. A. (1999). Antibiotic resistance found in wild rodents. Nature 401, 233-234.

Göbel, A., Thomsen, A., McArdell, C. S., Joss, A., and Giger, W. (2005). Occurrence and sorption behavior of sulfonamides, macrolides, and trimethoprim in activated sluge treatment. Environ. Sci. Technol. 39, 3981-3989.

Gräslund, S., Holmström, K., and Wahlström, A. (2003). A field survey of chemicals and biological products used in shrimp farming. Mar. Pollut. Bull. 46, 81-90.

Grave, K., Lingaas, E., Bangen, M., and Rønning, M. (1999). Surveillance of the overall consumption of antibacterial drugs in humans, domestic animals and farmed fish in Norway in 1992 and 1996. J. Antimicrob. Chemother. 43, 243-252.

Gullberg, E., Cao, S., Berg, O. G. Ilba, C., Sandegren, L., Hughes,
D., and Andersson, D. I. (2010) Selection of resistant bacteria at very low antibiotic concentrations. PLoS Pathog. 7, e1002158. doi:10.1371/journal.ppat.1002158

Hakanen, A., Kotilainen, P., Huovinen, P., Helenius, H., and Siitonen, A. (2001). Reduced fluoroquinolone susceptibility in Salmonella enterica serotypes in travelers returning from Southeast Asia. Emerging Infect. Dis. 7, 996-1003.

Hammerum, A. M., Sandvang, D., Andersen, S. R., Seyfarth, A. M. Porsbo, L. J., Frimodt-Møller, N. and Heuer, O. E. (2006). Detection of sul1, sul2 and sul3 in sulphonamide resistant Escherichia coli isolates obtained from healthy humans, pork and pigs in Denmark. Int. J. Food Microbiol. 106, 235-237.

Hernández, H. A., Sánchez, M. B., and Martínez, J. L. (2011) Quinolone resistance: much more than predicted. Front. Microbiol. 2:22 doi:10.3389/fmicb.2011.00022

Herold, S., Siebert, J., Huber, A., and Schmidt, H. (2005). Global expression of prophage genes in Escherichia coli O157:H7 strain EDL933 in response to Norfloxacin. Antimicrob. Agents Chemother. 49, 931-944.

Heuer, H., and Smalla, K. (2007). Manure and sulfadiazine synergistically increased bacterial antibiotic resistance in soil over at least two months. Environ. Microbiol. 9 , 657-666.

Hirai, H., Aoyama, H., Suzue, S. Irikura, T., Iyobe, S., and Mitsuhashi, S. (1986). Isolation and characterization of norfloxacin-resistant mutants of Escherichia coli K-12. Antimicrob. Agents Chemother. 30, 248-253.

Hirai, H., Suzue, S., Irikura, T., Iyobe, S., and Mitsuhashi, S. (1987). Mutations producing resistance to Norfloxacin in Pseudomonas aeruginosa. Antimicrob. Agents Chemother. 31, 582-586.

Hirsch, R., Ternes, T., Haberer, K. and Kratz, K.-L. (1999). Occurrence of antibiotics in the aquatic environment. Sci. Total Environ. 225, 109-118.

Hoa, P. T. P., Nonaka, L., Viet, P. H., and Suzuki, S. (2008). Detection of the sul1, sul2, and sul3 genes in sulfonamide-resistant bacteria from wastewater and shrimp ponds of north Vietnam. Sci. Total Environ. 405, 377-384

Hoa, P.T. P., Managaki, S., Nakada, N., Takada, H., Shimizu, A., Anh, D. H., Viet, P. H., and Suzuki, S. (2011). Antibiotic contamination and occurrence of antibiotic-resistant bacteria in aquatic environments of northern Vietnam. Sci. Total Environ. 409, 2894-2901.

Holmström, K., Gräslund, S. Wahlstrom, A., Poungshompoo, S., Bengtsson, B.-E., and Kautsky, N. (2003). Antibiotic use in shrimp farming and implications for environmental impacts and human health. Int. J. Food Sci. Technol. 38, 255-266.

Hop, L. T. (2003). Programs to improve production and consumption of animal source foods and malnutrition in Vietnam. J. Nutr. 133, 4006S4009S.

Kawamura-Sato, K., Wachino, J., Kondo, T., Ito, H., and Arakawa, Y. (2008). Reduction of disinfectant bactericidal activities in clinically isolated Acinetobacter species in the presence of organic material. J. Antimicrob. Chemother. 61, 568-576.

Kemper, N. (2008). Veterinary antibiotics in the aquatic and terrestrial environment. Ecol. Indic. 8, 1-13.

Kerrn, M. B., Klemmensen, T., FrimodtMøller, N., and Espersen, F. (2002). Susceptibility of Danish Escherichia coli strains isolated from urinary tract infections and bacteraemia, and distribution of sul genes conferring sulphonamide resistance. $J$. Antimicrob. Chemother. 50, 513-516.

Kim, S.-C., and Carlson, K. (2007). Temporal and spatial trends in the occurrence of human and veterinary antibiotics in aqueous and river sediment matrices. Environ. Sci. Technol. 41, 50-57.

Kim, S.-R., Nonaka, L., and Suzuki, S. (2004). Occurrence of tetracycline resistance genes tet $(\mathrm{M})$ and tet $(\mathrm{S})$ in bacteria from marine aquaculture sites. FEMS Microbiol. Lett. 237, 147-156.

Kobayashi, T., Nonaka, L., Maruyama, F., and Suzuki, S. (2007a). Molecular evidence for the ancient origin of the ribosomal protection protein that mediates tetracycline resistance in bacteria. J. Mol. Evol. 65, 228-235.

Kobayashi, T., Suehiro, F., Tuyen, B. C., and Suzuki, S. (2007b). Distribution and diversity of tetracycline resistance genes encoding ribosomal protection proteins in Mekong river sediments in Vietnam. FEMS Microbiol. Ecol. 59, 729-737.

Kolpin, D. W., Furlong, E. T., Meyer, M. T., Thurman, E. M., Zaugg, S. D., Barber, L. B., and Buxton, H. T. (2002). Pharmaceuticals, hormones, and other organic wastewater contaminants in U.S. streams, 1999-2000: a national reconnaissance. Environ. Sci. Technol. 36, 1202-1211. 
Kümmerer, K. (2003). Significance of antibiotics in the environment. $J$. Antimicrob. Chemother. 52, 5-7.

Kümmerer, K. (2004). Resistance in the environment. J. Antimicrob. Chemother. 54, 311-320.

Kümmerer, K. (2009a). Antibiotics in the aquatic environment - a review part I. Chemosphere 75, 417-434.

Kümmerer, K. (2009b). Antibiotics in the aquatic environment - a review part II. Chemosphere 75, 435-441.

Lai, H.-T., and Lin, J.-J. (2009). Degradation of oxolinic acid and flumequine in aquaculture pond waters and sediments. Chemosphere 75 , 462-468.

Le, T. X., and Munekage, Y. (2004). Residues of selected antibiotics in water and mud from shrimp ponds in mangrove areas in Vietnam. Mar. Pollut. Bull. 49, 922-929.

Le, T. X., Munekage, Y., and Kato, S.-I. (2005). Antibiotic resistance in bacteria from shrimp farming in mangrove areas. Sci. Total Environ. 349, 95-105.

Lindsey, M. E., Meyer, M., and Thurman, E. M. (2001). Analysis of trace levels of sulfonamide and tetracycline antimicrobials in groundwater and surface water using solid-phase extraction and liquid chromatography/mass spectrometry. Anal. Chem. 73, 4640-4646.

Livermore, D. M. (2005). Tigecycline: what is it, and where should it be used? J. Antimicrob. Chemother. 56, 611-614.

Loubeyre, C., Desnottes, J. F., and Moreau, N. (1993). Influence of subinhibitory concentrations of antibacterials on the surface properties and adhesion of Escherichia coli. J. Antimicrob. Chemother. 31, 37-45.

Managaki, S., Murata, A., Takada, H., Tuyen, B. C., and Chiem, N. H. (2007). Distribution of macrolides, sulfonamides and trimethoprim in tropical waters: ubiquitous occurrence of veterinary antibiotics in the Mekong delta. Environ. Sci. Technol. 41, 8004-8010.

McArdell, C. S., Molnar, E., Suter, M. J.-F., and Giger, W. (2003). Occurrence and fate of macrolide antibiotics in wastewater treatment plants and in the Glatt valley watershed, Switzerland. Environ. Sci. Technol. 37, 5479-5486.

Metcalfe, C., Miao, X.-S., Hua, W., Letcher, R., and Servos, M. (2004). "Pharmaceuticals in the Canadian environment," in Pharmaceuticals in the Environment-Sources, Fate, Effects and Risks, 2nd Edn, ed. K. Kümmerer (Berlin: SpringerVerlag), 67-90.
Neela, F. A., Nonaka, L., Rahman, M. H., and Suzuki, S. (2009). Transfer of the chromosomally encoded tetracycline resistance gene tet $(\mathrm{M})$ from marine bacteria to Escherichia coli and Enterococcus faecalis. World J. Microbiol. Biotechnol. 25, 1095-1101.

Nhiem, D. V., Paulsen, P., Suriyasathaporn, W., Smulders, F. J. M., Kyule, M. N., Baumann, M. P. O., Zessin, K. H., and Ngan, P. H. (2006). Preliminary analysis of tetracycline residues in marketed pork in Hanoi, Vietnam. Ann. N. Y. Acad. Sci. 1081, 534-542.

Nonaka, L., Ikeno, K., and Suzuki, S. (2007). Distribution of tetracycline resistance gene, tet( $\mathrm{M})$, in grampositive and gram-negative bacteria isolated from sediment and seawater at a coastal aquaculture site in Japan. Microbes Environ. 22, 355-364.

Nowara, A., Burhenne, J., and Spiteller, M. (1997). Binding of fluoroquinolone carboxylic acid derivatives to clay minerals. J. Agric. Food Chem. 45, 1459-1463.

Ogasawara, N., Tran, T. P., Ly, T. L. K., Nguyen, T. T., Iwata, T., Okatani, A. T., Watanabe, M., Taniguchil, T., Hirota, Y., and Hayashidani, H. (2008). Antimicrobial susceptibilities of Salmonella from domestic animals, food and human in the Mekong Delta, Vietnam. J. Vet. Med. Sci. 70, 1159-1164.

Ok, Y.-S., Kim, S.-C., Kim, K.-R., Lee, S.-S., Moon, D.-H., Lim, K.-J., Sung, J.-K., Hur, S.-O., and Yang, J.-E. (2011). Monitoring of selected veterinary antibiotics in environmental compartments near a composting facility in Gangwon Province, Korea. Environ. Monit. Assess. 174, 693-701.

Pei, R., Kim, S.-C., Carlson, K. H., and Pruden, A. (2006). Effect of river landscape on the sediment concentrations of antibiotics and corresponding antibiotic resistance genes (ARG). Water Res. 40, 2427-2435.

Perreten, V., and Boerlin, P. (2003). A new sulfonamide resistance gene (sul3) in Escherichia coli is widespread in the pig population of Switzerland. Antimicrob. Agents Chemother. 47, 1169-1172.

Petersen, A., and Dalsgaard, A. (2003). Species composition and antimicrobial resistance genes of Enterococcus spp., isolated from integrated and traditional fish farms in Thailand. Environ. Microbiol. 5, 395-402.

Picao, R. C., Poirel, L., Demarta, A., Silva, C. S. F., Corvaglia, A. R., Petrini, O., and Nordmann, P. (2008). Plasmid-mediated quinolone resistance in Aeromonas allosaccharophila recovered from a
Swiss lake. J. Antimicrob. Chemother. 62, 948-950.

Poirel, L., Liard, A., RodriguezMartinez, J. M., and Nordmann, P. (2005a). Vibrionaceae as a possible source of Qnr-like quinolone resistance determinants. J. Antimicrob. Chemother. 56, 1118-1121.

Poirel, L., Liard, A., RodriguezMartinez, J. M., Mammeri, H., Liard, A., and Nordmann, P. (2005b). Origin of plasmid-mediated quinolone resistance determinant QnrA. Antimicrob. Agents Chemother. 49, 3523-3525.

Pruden, A., Pei, R., Storteboon, H., and Carlson, K. H. (2006). Antibiotic resistance genes as emerging contaminants: studies in northern Colorado. Environ. Sci. Technol. 40, 7445-7450.

Rahman, M. H., Nonaka, L., Tago, R. and Suzuki, S. (2008a). Occurrence of two genotypes of tetracycline (TC) resistance gene tet $(\mathrm{M})$ in the TC-resistant bacteria in marine sediments of Japan. Environ. Sci. Technol. 42, 5055-5061.

Rahman, M. H., Sakamoto, K. Q., Nonaka, L., and Suzuki, S. (2008b). Occurrence and diversity of the tetracycline resistance gene tet $(\mathrm{M})$ in enteric bacteria of Antarctic Adelie penguins. J. Antimicrob. Chemother. 62, 627-628.

Roberts, M. C. (2005). Update on acquired tetracycline resistance genes. FEMS Microbiol. Lett. 245, 195-203.

Robicsek, A., Jacoby, G. A., and Hooper, D. C. (2006). The worldwide emergence of plasmid-mediated quinolone resistance. Lancet Infect. Dis. 6, 629-640.

Ross, J. I., Eady, E. A., Cove, J. H., and Cunliffe, W. J. (1998). 16S rRNA mutation associated with tetracycline resistance in a gram-positive bacterium. Antimicrob. Agents Chemother. 42, 1702-1705.

Samanidou, V. F., Christodoulou, E. A., and Papadoyannis, I. N (2005). Determination of fluoroquinolones in edible animal tissue samples by high performance liquid chromatography after solid phase extraction. J. Sep. Sci. 28 , 555-565.

Segura, P. A., François, M., Gagnon, C. and Sauve, S. (2009). Review of the occurrence of anti-infectives in contaminated wastewaters and natural and drinking waters. Environ. Health Perspect. 117, 675-684.

Sirichote, P., Bangtrakulnonth, A., Tianmanee, K., Unahalekhaka, A., Oulai, A., Chittaphithakchai, P., Kheowrod, P., and Hendriksen, R. S. (2010).
Serotypes and antimicrobial resistance of Salmonella enteritica ssp in central Thailand, 2001-1006. Southeast Asian Trop. J. Med. Public Health 41, 1405-1415.

Smets, B. F., and Barkay, T. (2005). Horizontal gene transfer: perspectives at a crossroads of scientific disciplines. Nat. Rev. Microbiol. 3, 675-678.

Stepanauskas, R., Glenn, T. C., Jagoe, C. H., Tuckfield, R. C., Lindell, A. H., King, C. J., and McArthur, V. J. (2006). Coselection for microbial resistance to metals and antibiotics in freshwater microcosms. Environ. Microbiol. 8, 1510-1514.

Storteboom, H., Arabi, M., Davis, J. G., Crimi, B., and Pruden, A. (2010a). Identification of antibioticresistance-gene molecular signatures suitable as tracers of pristine river, urban, and agricultural sources. Environ. Sci. Technol. 44, 1947-1953.

Storteboom, H., Arabi, M., Davis, J. G., Crimi, B., and Pruden, A. (2010b). Tracking antibiotic resistance genes in the South Platte River basin using molecular signatures of urban, agricultural, and pristine sources. Environ. Sci. Technol. 44, 7397-7404.

Suzuki, S., Kobayashi, T., Suehiro, F., Tuyen, B. C., and Tana, S. T. (2008). High occurrence rate of tetracycline (TC)-resistant bacteria and TC resistant genes relates to microbial diversity in sediment of Mekong river main waterway. Microbes Environ. 23, 149-152.

Suzuki, S., and Takada, H. (eds). (2009). Chemical Pollution in Indochina, Contamination Status, Ecosystem Impact and Remediation Technology. Hadano: Tokai University Press, 200.

Takasu, H., Suzuki, S., Reungsang, A., and Viet, P. H. (2011). Fluoroquinolone (FQ) contamination does not correlate with occurrence of FQ-resistant bacteria in aquatic environments of Vietnam and Thailand. Microbes Environ. 26, 135-143.

Tamminen, M., Karkman, A., Lõhmus, A., Muziasari, W. I., Takasu, H., Wada, S., Suzuki, S., and Virta, M. (2011). Tetracycline resistance genes persist at aquaculture farms in the absence of selection pressure. Environ. Sci. Technol. 45, 386-391.

Thaker, M., Spanogiannopoulos, P., and Wright, G. D. (2010). The tetracycline resistome. Cell. Mol. Life Sci.67, 419-431.

Thuy, H. T. T., Nga, L. P., and Loan, T. T. C. (2011). Antibiotic contaminants 
in coastal wetlands from Vietnamese shrimp farming. Environ. Sci. Pollut. Res. Int. 18, 835-841.

Underwood, J. C., Harvey, R. W., Metge, D. W., Repert, D. A., Baumgartner, L. K., Smith, R. L., Roane, T. M., and Barber, L. B(2011). Effect of the antimicrobial sulfamethoxazole on groundwater bacterial enrichment. Environ. Sci. Technol. 45, 3096-3101.

Vila, J., and Pachón, J. (2011). Acinetobacter baumannii resistant to everything: what should we do? Clin. Microbiol. Infect. 17, 955-956.

Vo, A. T. T., van Duijkeren, E., Gaastra, W., and Fluit, A. C. (2010). Antimicrobial resistance, class 1 integrons, and genomic island 1 in Salmonella isolated from Vietman. PLoS ONE 5, e9440. doi:10.1371/journal.pone.0009440

Wei, R., Ge, F., Huang, S., Chen, M., and Wanga, R. (2011). Occurrence of veterinary antibiotics in animal wastewater and surface water around farms in Jiangsu Province, China. Chemosphere 82, 1408-1414.

Yeh, P. J., Hegrenes, M. J., Aiden, P. A., and Kishony, R. (2009). Drug interactions and the evolution id antibiotic resistance. Nat. Rev. Microbiol. 7, 460-466.

Zhang, X.-X., and Zhang, T. (2011). Occurrence, abundance, and diversity of tetracycline resistance genes in 15 sewage treatment plants across China and other global locations. Environ. Sci. Technol. 45, 2598-2604.

Zhang, X.-X., Zhang, T., and Fang, H. P. P. (2009). Antibiotic resistance genes in water environment. Appl. Microbiol. Biotechnol. 82, 397-414.

Conflict of Interest Statement: The authors declare that the research was conducted in the absence of any commercial or financial relationships that could be construed as a potential conflict of interest.

Received: 11 November 2011; accepted 07 February 2012; published online: 22 February 2012
Citation: Suzuki S and Hoa PTP (2012) Distribution of quinolones, sulfonamides, tetracyclines in aquatic environment and antibiotic resistance in Indochina. Front. Microbio. 3:67. doi: 10.3389/fmicb.2012.00067

This article was submitted to Frontiers in Antimicrobials, Resistance and Chemotherapy, a specialty of Frontiers in Microbiology.

Copyright (ㄷ) 2012 Suzuki and Hoa. This is an open-access article distributed under the terms of the Creative Commons Attribution Non Commercial License, which permits non-commercial use, distribution, and reproduction in other forums, provided the original authors and source are credited. 